\title{
Hisse Senedi Getirileri ve Kârlılık Arasındaki İlișki: Borsa İstanbul Endeksinde İşlem Gören İşletmelerin Analizi
}

\author{
Hülya CENGİZ ${ }^{1}$ \\ A. Seden Özbek PÜSKÜL ${ }^{2}$
}

\section{Özet}

Bu çalışmada Borsa İstanbul'da işlem gören işletmelerin hisse senedi getirileri ile işletme kârlılığı arasındaki ilişki incelenmiștir. Çalıșmanın amacı hisse getirisi ile ilişkili kârlılık oranlarını tespit ederek, hisse senedi yatırımı kararlarında yol gösterici olmaktır. Bu doğrultuda, panel veri seti oluşturulmuş, Stata Veri Analizi ve İstatistik Programı kullanılarak panel data analizi yapılmıştır. Analizde, birim ve zaman etkilerinin varlığı sınanmış, tesadüfi etkiler tahmincisinin uygun olduğuna karar verilmiştir. Ayrıca, panel veri modellerinin üç temel varsayımı, otokorelasyon, heteroskedasite ve birimler arası korelasyonun varlığı test edilmiştir. Bu varsayımların bozulduğu saptanıp dirençli tahminciler ile tahmin yapılmıştır. Bu çalışma, öz kaynak kârlılığı ve brüt satış kârlılığındaki artışın hisse senedi getirilerini artırdığını ve faaliyet kârı oranındaki artışın hisse senedi getirilerini azalttığını göstermiştir. Bu çalışmanın sonuçlarına göre, işletmelerin kârlılık oranları kullanılarak hisse senedi getirisi tahmini yapılabilir.

Anahtar Kelimeler: Kârlılık, hisse senedi getirisi, Borsa İstanbul, panel veri analizi

\section{The Relation between Stock Returns and Profitability: An Analysis of Companies Listed in Borsa Istanbul}

\begin{abstract}
In this study, the relationship between the stock returns and the firm profitability of the listed companies in Borsa Istanbul is investigated. The aim of the study is to provide guidance for stock investment decision by determining the related profitability ratios. In this respect, the panel dataset was collected, and panel data analysis was performed using Stata Data Analysis and Statistical Software. In the analysis, the existence of unit and time effects were tested, and it was decided that random effect model was appropriate. Also, three assumptions of panel data that are autocorrelation, heteroscedasticity, and cross-sectional independence were tested. Since these assumptions were violated, robust estimators were used. This study showed that an increased profitability of equity and gross sales margin led an increase in the stock returns while an increase in operating margin led a decrease in the stock returns. These results suggest that the profitability ratios of the firms can be useful to estimate stock returns.
\end{abstract}

Keywords: Profitability, financial ratios, stock returns, Borsa Istanbul

\section{Giriş}

Hisse senetleri önemli yatım araçlarından bir tanesidir. Yatırımcının hisse senedi yatırımından beklediği getiriyi elde edilebilmesi için, hisse senetlerinin ve piyasa koşullarının iyi analiz edilmesi gerekmektedir. Hisse senedi yatırımına karar verebilmek için temel analiz yapılabilmektedir. Temel analiz ile yatırım yapılacak hissenin finansal yapısı, finansal oranlar ile belirlenmektedir. İşletmelerin temel finansal tabloları kullanılarak hesaplanan finansal oranlar, işletmelerin likidite durumu, faaliyet yapısı, kârlılı̆̆ 1 ve mali yapısı belirlenebilmektedir.

\footnotetext{
${ }^{1}$ Arş.Gör.Dr., Yıldız Teknik Üniversitesi, Sosyal Bilimler Enstitüsü, hucengiz@yildiz.edu.tr ${ }^{2}$ Yrd.Doç.Dr., Trakya Üniversitesi, Keşan Yusuf Çapraz Uygulamalı Bilimler Yüksekokulu, asedenozbek@trakya.edu.tr
} 
Borsa İstanbul (BIST), Sermaye Piyasası Kanunu'na göre kurulmuş ve Sermaye Piyasası Kurulu'nun gözetimi ve denetimi altında faaliyetlerini sürdüren, Türkiye'nin tek organize hisse senedi piyasasıdır. BIST Hisse Senedi (Pay) Piyasası'nda farklı sektörlerden şirketlerin payları, yeni pay alma hakları, borsa yatırım fonları, varantlar ve sertifikalar işlem görmekte ve yabancı yatırımcılar için likit, şeffaf ve güvenli yatırım ortamı sağlanmaktadır (Borsa İstanbul, 2016). BIST' de işlem gören şirketlerin, denetimden geçmiş finansal raporları kamuoyu ile paylaşılmakta ve Kamuyu Aydınlatma Platformu'ndan (KAP) yayınlanmaktadır. Küçük ve orta büyüklükteki işletmelerin çoğunlukta olduğu ülkemizde, işletimlerin borsada işlem görmesi, kurumsallaşma ile şeffaf ve güvenilir yatırım ortamına zemin oluşturmaktadır. Ayrıca finansal tablolarının kamuoyu ile paylaşılması akademik çalışmalarda veri seti oluşturulmasına olanak sağlayarak analizlerin konusunu oluşturmaktadır.

Çalışmanın ilk bölümümde, hisse senedi getirileri ile finansal oranlar arasındaki ilişkiyi tespit etmeye yönelik yapılan ulusal ve uluslararası literatür incelenmiş; ikinci bölümünde kârlılık oranları ile hisse senedi getirileri arasındaki ilişkinin varlığının test edilebilmesi için kullanılan veriler ve araştırmanın metodoloji açıklanmış, araştırma problemi tanımlanmış ve analizin sonuçlarına yer verilmiştir.

\section{Literatür}

Şanghay Borsasında işlem gören ve yıllık ortalama hisse senedi getirisi en yüksek \%10'luk dilimde yer alan işletmelerin hisse senedi getirileri ile finansal oranları arasındaki ilişkilerin incelendiği çalışmada; 1996-1998 yılları arasında, hisse senedi getirileri ile toplam varlık devir hızı, hisse başına kâr, kâr marjı, aktif kârlılık, özsermaye kârlılığı ve satışlardaki kârlılık oranları arasında anlamlı ilişki bulunmuştur (Dehuan \& Jin, 2008).

Mısır'da faaliyet gösteren 46 işletmenin1996-2000 yılları arasındaki, likidite, varlık kullanım, kârlılık, mali yapı ve sabit yükümlülükleri karşılama durumlarını ölçen finansal oranları ile hisse senedi getirileri arasındaki doğrusal ve doğrusal olmayan ilişkiler incelenmiş; özsermaye kârlılığ ile hisse senedi getirisi arasında doğrusal ilişki bulunmuştur (Omran \& Ragab, 2004).

Khan vd. (Khan, Aamir, Qayyum, Nasir, \& Khan, 2011) çalışmalarında, Pakistan Borsası'nda işlem gören işletmelerin, temettü verim oranı, hisse başına kâr, özsermaye kârlılığı ve vergi sonrası kârlılık ile hisse senedi fiyatı arasında pozitif ilişki, dağıtılmayan kârlar oranı ile hisse senedi fiyatı arasında negatif bir ilişki olduğunu bulmuşlardır. Pakistan Borsası için yapılan bir diğer çalışmada ise; hisse senedi fiyatı ile temettü verim oranı arasında pozitif bir ilişki, temettü ödeme oranıyla da negatif bir ilişki bulunmuştur (Habib \& Khan, 2012).

Hisse senedi getirileri ile finansal oranlar arasındaki ilişki, Türkiye'de Borsa İstanbul'da işlem gören işletmeler için farklı dönemlerde farklı finansal oranlar kullanılarak test edilmiştir. Ege ve Bayrakdaroğlu (Ege \& Bayrakdaroğlu, 2009) 2004 yılında BIST-30 endeksinde yer alan hisse senetleri ile fiyat/kazanç oranı, nakit oranı, toplam varlıkların devir hızı oranı arasında ilişki bulmuşlardır. Oruç (Oruç, 2010) ise 1997-2010 yılları arasında BIST-100 endeksi için, bir önceki 
yıl (t-1) aktif devir hızı, satış büyüklüğü, varlık büyümesi ve piyasa değeri defter değeri oranlarının $\mathrm{t}$ dönemindeki hisse senedi getirileri üzerinde etkili olduğu sonucunu bulmuştur. Aktaş (Aktas, 2009) ise asit-test oranı ile faaliyetlerden sağlanan nakit akımının öz sermayeye oranı arasında 1995-1999 dönemleri arasında; brüt satış karlılığı ve net satış karlılığ dönemleri arasında anlamlı ilişkiler bulmuştur. Büyükşalvarcı (Büyükşalvarci, 2010) ise çalışmasında BIST imalat sektöründe işlem gören hisse senedi getirileri ile varlıkların etkin kullanımı, mali yapı, kârlılık ve borsa performans durumlarını temsil eden oranlar arasındaki ilişkinin doğrusal olup olmadığını 2009 yılı için analiz etmiş ve doğrusal ilişkilerin incelenen dönemde tüm oranlar için geçerli olmadığı sonucu bulmuştur. Sakarya ve Yıldırım (Sakarya \& Yildirim, 2016) Borsa İstanbul'da işlem gören on dört enerji şirketinin finansal performansları ile hisse senedi getirileri arasındaki ilişkiyi incelenmişlerdir. Bunun için, hesaplanan oranlar; ilk önce çok kriterli karar verme yöntemlerinden birisi olan TOPSIS yöntemi kullanılarak genel şirket performansını gösteren TOPSIS skorlarına dönüştürülmüştür. Daha sonra bu skorlar ile şirketlerin yıllık ortalama getirileri arasındaki ilişki panel veri analizi ile test edilmiştir. Test sonuçlarında şirketlere ait TOPSIS skorları ile hisse senedi getirileri arasında kısa dönemli bir eş-bütünleşme olduğu sonucuna ulaşılmışıtır. Ancak TOPSIS skorları ile hisse senedi getirileri arasında karşıllklı bir nedensellik sonucuna rastlanılmamıştır. TOPSIS ile performans değerleme yöntemi kullanılarak yapılan bir diğer çalışmada (Ozen, Yesildag, \& Soba, 2015) ise; BIST Gıda Endeksinden seçilen dört işletmenin, performansla hisse senedi getirileri arasındaki ilişki analiz edilmiştir. Analiz sonucunda performans ile getireler arasında ilişki bulunamazken; finansal oranlar ile getiri arasında sadece bir işletmenin kârlılık oranları ile getirileri arasında istatistiksel açıdan anlamlı pozitif bir ilişki bulunmuştur.

Borsa İstanbul'da 2005-2011 döneminde imalat sanayinde sürekli işlem gören 57 işletmenin, hisse senedi fiyatı ile kısa vadeli yabancı kaynak oranı, maddi duran varlıklar/öz kaynak oranı, öz kaynak kârlılık oranı ve fiyat/ kazanç oranı arasında pozitif yönlü bir ilişki; alacak ve stok devir hızı, toplam borçların/toplam aktiflere oranı ve kısa vadeli yabancı kaynak oranı ile hisse senedi fiyatı arasında ise negatif yönlü ilişki; cari oran, net kâr/toplam aktifler, piyasa değeri/defter değeri ve temettü verimi arasında ise ilişki bulunamamıştır (Güngör \& Kaygin, 2015). Y1lgör (Yılgör, 2005) ise, işletmelerin finansal yapısındaki değişikliklerin hisse senedi getirileri üzerindeki etkisini ve bu değişimlerin yatırımcılar tarafından nasıl algılandığını portföy oluşturarak, 1996-2000 döneminde incelemişlerdir. Analizde borç kullanma düzeyindeki artışın yatırımcılar tarafından, belirli dönemlerde işletmenin geleceğini etkileyen bir bilgi olarak kullanıldığını ancak bilginin devamlılık göstermediğini bulmuşlardır.

Literatürde BIST-30, BIST-100 ve BIST imalat sanayini kapsayan farkl1 dönemlerdeki çalışmalarda, farklı finansal oranların hisse senedi getirilerini açıklamakta etkili olduğu sonucu bulunmuştur. Bu çalışmada BIST'te yer alan işletmelerden, finans sektörü hariç, süreklilik gösteren tüm işletmelerin, kârlık oranları ile hisse senedi getirileri arasında istatistiksel olarak anlamlı ilişkilerinin olup olmadığı var ise hangi yönde olduğu 2011-2015 yıllar arasında test edilmiştir. 


\section{Hisse Senedi Getirisi ile Finansal Oranlar Arasındaki İlişkinin Analizi}

Araştırmanın amacı hisse senedi getirileri ile kârlılık oranları arasında anlamlı ilișkiler olup olmadığını belirlemektir. Bu doğrultuda Borsa İstanbul'da işlem gören işletmelerin hisse senedi getirileri ile finansal oranları arasındaki ilişki incelenmiştir.

\subsection{Araştırmada Kullanılan Veriler ve Metodolojisi}

Borsa İstanbul'da 2011-2015 y1lları arasında sürekli işlem gören işletmelerin finansal oranları ve hisse senedi getirileri hesaplanmıştır. Finansal oranların hesaplanmasında Kamuyu Aydınlatma Platformunda ("Kamuyu Aydınatma Platformu," 2016) kamuoyuna açıklanan finansal raporlardan yararlanılmıştır. Hisse senedi getirileri olarak yıllık ortalama hisse senedi getirileri kullanılmış, yıllık ortalamalar ise Borsa İstanbul web sayfasında ("Borsa İstanbul," 2016) yer alan aylık ortalama hisse senedi getirileri esas alınarak hesaplanmıştır.

Hisse senedi getirileri ise Borsa İstanbul web sayfasında ("Borsa İstanbul," 2016) yer alan, aylık ortalama hisse senedi getirileri esas alınarak, yıllık ortalama hisse senedi getirileri hesaplanmıştır.

Analizde kullanılan karlılık oranları; net kâr marjı, faaliyet kârlılığı, öz kaynak kârlılık, brüt satış kârlılık ve aktif kârlılık oranlarıdır. Bu oranların ve hesaplama yöntemleri Tablo 1'de gösterilmiştir.

\section{Tablo 1: Analizde Kullanılan Kârlılık Oranları ve Hesaplama Yöntemleri}

\begin{tabular}{ll} 
Finansal Oranlar & Hesaplama Yöntemi \\
\hline Net kâr marjı & Net kâr / Net satışlar \\
Faaliyet kârı oranı & Faaliyet kârı / Net satışlar \\
Öz kaynak kârlılık oranı & Dönem net kârı / Öz kaynaklar \\
Brüt satış kârı oranı & Brüt kâr / Net Satışlar \\
Aktif kârlılığı & Net kâr / Ortalama aktif toplamı \\
\hline
\end{tabular}

Borsa İstanbul'da finans sektörü dışında sürekli işlem gören 228 işletmenin yıllara göre finansal oranları ve hisse senedi getirileri hesaplanarak panel veri seti oluşturulmuştur. Panel veri hanehalkı, ülkeler, firmalar gibi yatay kesit gözlemlerinin belli bir zaman dönemi ile ifade edilmesidir (Baltagi, 2005). Stata11 (Stata Data Analysis and Statistical Software) programı kullanılarak hisse senedi getirileri ile finansal oranlar arasındaki ilișki analiz edilmiştir. Panel veri modellerinden klasik model havuzlanmış en küçük kareler yöntemi, sabit etkiler ve tesadüfi etkiler modellerinden uygun olan tahmin yöntemi seçilmiş, modelin geçerliliğini test etmek için, birim etkileri, heteroskedasite ve otokorelasyon sınanmış, gerekli görülmesi durumunda dirençli tahminciler kullanılarak tahmin yapılmıştır. Ayrıca panel verinin durağanlığını test etmek için birim kök testi yapılmıştır. 


\subsection{Araştırma Problemi}

Çalışmada yatay kesit verisi olarak İstanbul Borsa'da işlem gören işletmeler kullanılarak, hisse senedi getirileri ile finansal oranlar arasında ilişki kurulmak istenmektedir. Panel veri modeli aşağıdaki gibi kurulmuştur.

$\mathrm{G}_{\mathrm{it}}=\alpha+\beta_{1} \mathrm{KM}_{\mathrm{it}}+\beta_{2} \mathrm{FK}_{\mathrm{it}}+\beta_{3} \mathrm{OK}_{\mathrm{it}}+\beta_{4} \mathrm{BK}_{\mathrm{it}}+\beta_{5} \mathrm{AKO}_{\mathrm{it}}+\mathrm{u}_{\mathrm{it}}$

Modelde; bağımlı değişken G: hisse senedi getirileri; bağımsız değişkenler ise KM: Net kâr marjı, FM: Faaliyet kârı oranı, OK: Öz kaynak kârlılık oranı, BK: Brüt satış kârı oranı AK: Aktif kârlılık oranıdır. $\alpha$ Sabit parametreyi, $\beta$ eğim parametrelerini, $u$ hata terimini, $t$ alt indisi yılları, $i$ alt indisi hisse senedi borsada işlem gören şirketleri ifade etmektedir. Araştırmanın hipotezleri Tablo 2'de gösterilmiştir.

Tablo 2: Araştırmanın Hipotezi ve Alt Hipotezleri

\section{Temel Hipotez}

$\mathrm{H}_{0} ; \beta=0$ (Hisse senedi getirileri ile kârlılık oranları arasında ilişki yoktur)

$\mathrm{H}_{1} ; \beta \neq 0$ (Hisse senedi getirileri ile kârlılık oranları arasında ilişki vardır)

\section{Alt Hipotezler}

$\mathrm{H}_{1} \quad$ "Hisse senedi getirileri ile net kâr marjı arasında ilişki vardır"

$\mathrm{H}_{2}$ "Hisse senedi getirileri ile faaliyet kârı oranı arasında ilişki vardır"

$\mathrm{H}_{3}$ "Hisse senedi getirileri ile öz kaynak kârlılık oranı arasında ilişki vardır"

$\mathrm{H}_{4}$ "Hisse senedi getirileri ile brüt satış kârı oranı arasında ilişki vardır"

$\mathrm{H}_{5} \quad$ "Hisse senedi getirileri ile aktif kârlılık oranı arasında ilişki vardır"

\subsection{Araştırma Sonucu}

Panel veri analizinde verilerin kesitsel boyutunun yanı sıra zaman boyutunun da analizde yer alması asimptotik davranışa sebep olabilmektedir. $\mathrm{Bu}$ nedenle verinin durağanlığ incelenmiştir. Panel serilerde birimler arasında korelasyon olursa, testlerin asimptotik özellikleri etkilenebilmekte bu nedenle birimler arası korelasyonun varlığında farklı birim kök testleri geliştirilmiştir (Güriş, 2015). Bu çalışmada durağanlık, ikinci nesil birim kök testlerinden, Pesaran panel birim kök testi ile birinci ve ikinci mertebeden durağanlık sınanmıştır. Aşağıda belirtilen Pesaran test sonuçlarına (Tablo 3) göre t-bar istatistiği, cv10, cv5 ve cvl $(\% 10, \% 5$ ve\%1) güven düzeyinde, verilen kritik değerlerden büyük olduğu için veri setindeki değişkenler durağan bulunmuştur. Panel dengeli panel veridir.

Tablo 3: Pesaran Panel Birim Kök Testi Sonuçları

\begin{tabular}{ll}
\hline & cv10: $-1,990$ \\
t-bar: 2,610 & cv5 : $-2,080$ \\
& cv1 : $-2,250$
\end{tabular}


Kullanılacak tahmin yöntemleri arasında karar verebilmek için klasik modelin, sabit etkiler ve tesadüfi etkiler modellerinin testleri yapılmış ve uygun tahminci seçimi yapılmıştır. Genel olarak, bütün gözlemlerin homojen olduğu yani birim ve/veya zaman etkilerinin olmadığı düşünülüyorsa, klasik modelin; birim ve/veya zaman etkilerinin olduğu düşünülüyorsa sabit veya tesadüfi etkiler modelinin kullanılmasının daha uygun olduğu söylenebilmektedir (Yerdelen Tatoğlu, 2013).

Klasik modelde, birim etkinin varlığını sınamak için $F$ testi, olabilirlik oranı (LR) testi; zaman etkisinin varlığını test etmek için LR testi yapılmıştır. Birim etkinin varlığını sınamak için yapılan F testi ile tüm birim etkilerin sıfıra eşit olduğu hipotezi (H0 : $\mu \mathrm{i}=0$ ) sinanmaktadır (Yerdelen Tatoğlu, 2013). F test istatistiği sonucu anlamlılık değerleri aşağıdaki (Tablo 4) gibi bulunmuştur.

Tablo 4: Birim Etkinin Varlığı - F Testi Sonuçları

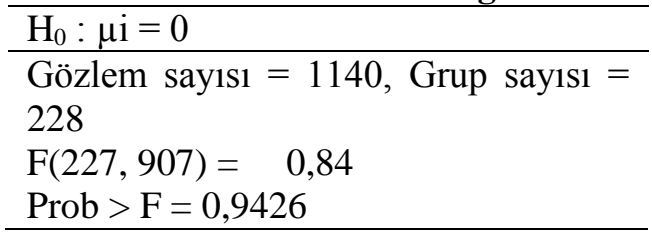

Sonuçlara göre birim etkinin sıfira eşit olduğu $\mathrm{H}_{0}$ hipotezi kabul edilmekte, dolayısıyla birim etkinin olmadığ

Birim etkinin varlığı LR testi ile sınandığında, klasik modeli tesadüfi etkiler modeline karş1 test etmek için, $\mathrm{H}_{0}$ hipotezi klasik modelin uygun olduğu şeklinde $\left(\mathrm{H}_{0}: \sigma_{\mathrm{i}}=0\right)$ kurulmuştur. LR test sonuçları anlamlılık değerleri aşağıdaki (Tablo 5) gibi bulunmuştur. Sonuçlara göre birim etkinin sıfıra eşit olduğu $\mathrm{H}_{0}$ hipotezi kabul edilmekte, dolayısıyla birim etkinin olmadığı anlaşılmaktadır.

\section{Tablo 5: Birim Etkinin Varlığı - LR Testi Sonuçları}

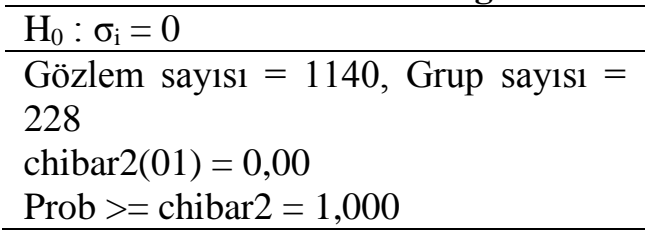

Zaman etkilerinin standart hatalarının sıfira eşit olduğu, yani klasik modelin uygun olduğu temel hipotezi $\left(\mathrm{H}_{0}: \sigma_{\lambda}=0\right)$, LR testi (Yerdelen Tatoğlu, 2013) ile sınanmıştır. Test sonucuna (Tablo 6) göre zaman etkilerinin standart hatalarının sıfıra eşit oluğu hipotezi reddedilmektedir dolayısı ile klasik modelin uygun olduğu hipotezi reddedilmektedir. 
Tablo 6: Zaman Etkisinin Varlığı - LR Testi Sonuçları

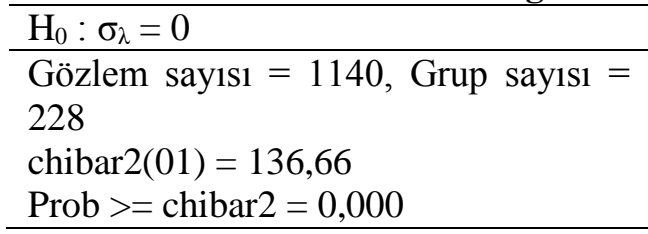

Yapılan testler sonucunda birim ve/veya zaman etkilerinin olduğu anlaşıldığından bu etkilerin sabit mi tesadüfi mi olduğuna karar verilmesi gerekmektedir (Yerdelen Tatoğlu, 2013). Hausman ile tesadüfi etkiler modeli, sabit etkiler modeline karşı sınanacaktır. $\mathrm{H}_{0}$ hipotezi, parametreler arasındaki fark sistematik değildir yani tesadüfi etkiler modeli uygundur şeklinde kurulmaktadır (Yerdelen Tatoğlu, 2013).

Tablo 7: Hausman Testi Sonuçları

\begin{tabular}{|c|c|c|c|c|}
\hline & \multicolumn{4}{|c|}{ Coefficients } \\
\hline & Sabit Etki & Tesadüfi Etki & (b-B) & $\operatorname{sqrt}\left(\operatorname{diag}\left(V_{-} \_b-V_{-} B\right)\right)$ \\
\hline KM & $\begin{array}{c}\text { (b) } \\
-0.0006224\end{array}$ & $\begin{array}{c}\text { (B) } \\
0.0002084\end{array}$ & Difference & $\begin{array}{l}\text { S.E. } \\
0,0004139\end{array}$ \\
\hline FK & $-0,0020054$ & $-0,0017104$ & $-0,0002949$ & 0,0007459 \\
\hline OK & 0,0029559 & 0,003377 & $-0,0004211$ & 0,0009029 \\
\hline BK & 0,002745 & 0,0101777 & $-0,0074327$ & 0,0058267 \\
\hline $\mathrm{AKO}$ & 0,0094601 & 0,0152231 & $-0,005763$ & 0,0038996 \\
\hline \multicolumn{5}{|c|}{$\begin{array}{l}\mathrm{b}=\text { consistent under } \mathrm{Ho} \text { and } \mathrm{H}_{1} ; \text { obtained from xtreg } \\
\mathrm{B}=\text { inconsistent under } \mathrm{H}_{1} \text {, efficient under } \mathrm{Ho} \text {; obtained from xtreg }\end{array}$} \\
\hline \multicolumn{5}{|c|}{$\begin{aligned} \operatorname{chi} 2(5) & =(b-B)^{\prime}\left[\left(V_{-} b-V_{-} B\right)^{\wedge}(-1)\right](b-B) \\
& =8.17\end{aligned}$} \\
\hline Prob> & $=0,1474$ & & & \\
\hline
\end{tabular}

Hausman testi sonucunda tesadüfi etkiler modelinin geçerli olduğu anlaşılmakta, $\mathrm{H}_{0}$ hipotezi kabul edilmekte, sabit etkiler tahmincisinin geçersiz olduğu anlaşılmaktadır (Tablo 7).

Panel veri modellerinde hata teriminin birim içerisinde ve birimlere göre eşit varyanslı (homoskedastik) olduğu varsayılmaktadır. Ayrıca hata teriminin dönemsel ve uzamsal korelasyonsuz olduğu, yani otokorelasyonsuz ve birimlerarası korelasyonsuz olduğu varsayımları yapılmaktadır (Yerdelen Tatoğlu, 2013). Bu nedenle bu üç temel varsayım test edilecektir.

Tesadüfi etkiler modelinde değişen varyans (heteroskedasite), Levene, Brown ve Forsythe'nin testi ile sınanmıştır. F testi sonucunda $p$ değeri 0,00 ve 0,931'dir (Tablo 8). Test olasılıkları ile karşılaştırıldı ğında $\mathrm{H}_{0}$ hipotezi red edilmekte ve varyansların sabit olmadığı yani heteroskedasitenin olduğu anlaşılmaktadır. 
Tablo 8: Tesadüfi Etkiler Modelinde Heteroskedasite - Levene, Brown ve Forsythe'nin Testi Sonuçları

\begin{tabular}{lll}
\hline W0 $=2,65970974$ & $\operatorname{df}(227,912)$ & Pr $>F=0,00000000$ \\
W50 $=0,85166084$ & $\operatorname{df}(227,912)$ & Pr $>F=0,93110912$ \\
W10 $=2,65970974$ & $\operatorname{df}(227,912)$ & Pr $>F=0,00000000$ \\
\hline
\end{tabular}

Tesadüfi etkiler modelinde otokorelasyonun varlığı Bhargava, Franzini ve Narendranathan'ın Durbin-Watson testi ve Baltagi-Wu'nun yerel en iyi değişmez testleri ve varlı̆̆ 1 Lagrange çarpanmı (LM) ve düzeltilmiş Lagrange çarpanı (ALM) testleri ile de sınanmıştır. $\mathrm{H}_{0}$ hipotezi her iki test için de otokorelasyon yoktur şeklinde kurulmaktadır. Test sonuçları Tablo 9'da sunulmuştur. Bhargava, Franzini ve Narendranathan'in Durbin-Watson testi ve Baltagi-Wu'nun yerel en iyi değişmez testlerine göre kritik değerler 2'den büyük olduğu için otokorelasyonun olmadığı anlaşılmaktadır. LM, ALM ve birleşik LM test sonuçlarına göre otokorelasyon vardır.

Tablo 9: Tesadüfi Etkiler Modelinde Otokorelasyon Test Sonuçları

\section{Bhargava, Franzini ve Narendranathan'm Durbin-Watson Testi ve}

Baltagi-Wu

Modified Bhargava et al. Durbin-Watson $=2,0022002$

Baltagi-Wu LBI = 2,4893445

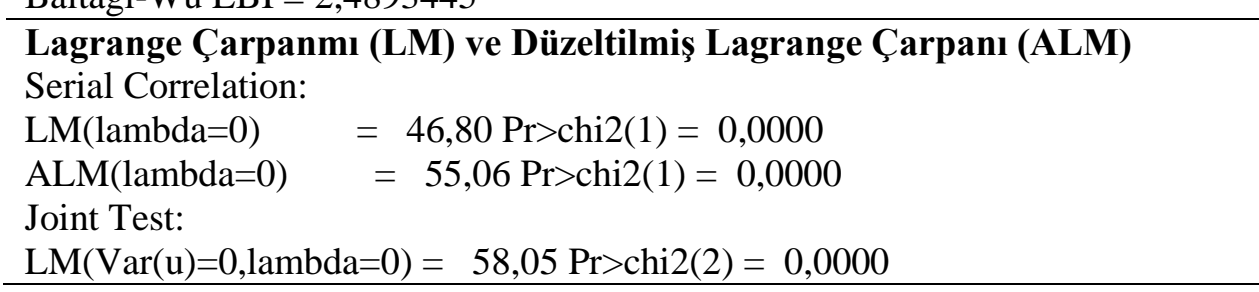

Tesadüfi etkiler modelinde birimler arası korelasyon Pesaran, Friedman ve Frees'in testleri ile sınanmış, test sonuçları Tablo 10'de sunulmuştur.

Tablo 10: Tesadüfi Etkiler Modelinde Birimler Arası Korelasyon Testleri Sonuçları

Pesaran Testi

Pesaran's test of cross sectional independence $=82,683 ; \operatorname{Pr}=0,0000$

Friedman Testi

Friedman's test of cross sectional independence $=217,607 ; \operatorname{Pr}=0,6612$

Frees Testi

Frees' test of cross sectional independence $=10,004$

Critical values from Frees' $\mathrm{Q}$ distribution

$$
\begin{array}{ll}
\text { alpha }=0,10: & 0,4892 \\
\text { alpha }=0,05: & 0,6860 \\
\text { alpha }=0,01: & 1,1046
\end{array}
$$


Pesaran test sonuçlarına göre $\mathrm{H}_{0}$ hipotezi, birimler arası korelasyon yoktur hipotezi reddedilmekte, birimler arası korelasyonun olduğu anlaşılmaktadır. Friedman testine göre $\mathrm{H}_{0}$ hipotezi kabul edilmekte birimler arası korelasyonun olmadığı anlaşılmaktadır. Frees testinde ise test istatistiği verilen kritik değerlerden büyük olduğu için birimler arası korelasyonun olduğu görülmektedir.

Yapılan testler sonucunda heteroskedasitenin, otokorelasyonun ve birimler arası korelasyonun olduğu anlaşılmaktadır. $\mathrm{Bu}$ nedenle dirençli tahminciler ile tahmin yapılacaktır. Dirençli tahminciler ile yapılan test sonuçları Tablo 11'de gösterilmiştir.

Tablo 11: Dirençli Tahmincilere Göre Test Sonuçları

\begin{tabular}{llll}
\hline Variable & Nonrobust & Robust & AR1 \\
\hline KM & 0,00021 & 0,00021 & 0,00021 \\
& $5,1 \mathrm{e}-04$ & $5,1 \mathrm{e}-04$ & $5,1 \mathrm{e}-04$ \\
& 0,681 & 0,681 & 0,681 \\
\hline FK & $-0,00171$ & $-0,00171$ & $-0,00171$ \\
& $9,9 \mathrm{e}-04$ & $9,9 \mathrm{e}-04$ & $9,9 \mathrm{e}-04$ \\
& 0,085 & 0,085 & 0,085 \\
\hline OK & 0,00338 & 0,00338 & 0,00338 \\
& 0,0014 & 0,0014 & 0,0014 \\
& 0,012 & 0,016 & 0,013 \\
\hline BK & 0,0102 & 0,0102 & 0,0102 \\
& 0,0048 & 0,0047 & 0,0048 \\
& 0,034 & 0,029 & 0,034 \\
\hline AKO & 0,0152 & 0,0152 & 0,0152 \\
& 0,0056 & 0,0116 & 0,0056 \\
& 0,007 & 0,188 & 0,007 \\
\hline cons & 0,00372 & 0,00372 & 0,00372 \\
& 0,0017 & 0,0016 & 0,0017 \\
& 0,025 & 0,0017 & 0,025 \\
\hline chi2 & 19,957 & 16,783 & 19,913 \\
$\mathrm{p}$ & 0,001 & 0,005 & \\
\hline & & & legend: b/se/p \\
\hline
\end{tabular}

Tablo 11'de ilk sütunda değişkenler, ikinci sütunda (nonrobust) klasik tesadüfi etkiler tahmincisi, üçüncü sütunda (robust) heteroskedasite ve otokorelasyon varlığında dirençli tesadüfi etkiler tahmincisi ve dördüncü sütunda AR(1) korelasyona izin veren tesadüfi etkiler tahmincileri yer almaktadır. Genel olarak klasik tesadüfi etkiler, heteroskedasite ve otokorelasyon varlığında dirençli tesadüfi etkiler ve AR(1) korelasyona izin veren tesadüfi etkiler tahmincilerinin parametreleri aynı sonucu vermektedir. Ancak varyanslarından dolayı standart hataları değiştiğinden $t$ istatistikleri değişmiştir (Yerdelen Tatoğlu, 2013). Wald testi (chi2) sonucuna göre model genel olarak anlamlıdır. Tüm tahmincilerine göre 
net kâr marjının hisse senedi getirilerini açıklayıcılığı anlamsız; faaliyet kârı oranı, öz kaynak kârlılık oranı ve brüt satış kârı oranının hisse senedi getirilerini açıklamakta anlamlı olduğu görülmektedir. Aktif kârlılığı oranının hisse senedi getirilerini açıklayıcıllğı ise heteroskedasite ve otokorelasyon varlığında dirençli tesadüfi etkiler tahmincisi ile sinandığında anlamsız, klasik tesadüfi etkiler tahmincisi ve AR(1) korelasyona izin veren tesadüfi etkiler tahmincileri ile sınandığında ise anlamlı ilişki bulunmaktadır. Modelde heteroskedasite ve otokorelasyon varlığındaki dirençli tahmincinin kullanılması uygun görülmektedir. Sonuçlara göre faaliyet kârı oranındaki \%1'lik artış hisse senedi getirilerini \%0,17 azaltmakta; öz kaynak kârlılığındaki \%1'lik artış hisse senedi getirilerini \%0,33 artırmakta; brüt satış kârı oranındaki \%1'lik artış hisse senedi getirilerini \%1,02 oranında artırmaktadır. Net kâr marjı ve aktif kârlılığı arasında ise anlamlı ilişki bulunamamıştır.

\section{Sonuç}

Hisse senetleri yatırımcıların ilgi duyduğu ve riski yüksek olan yatırım araçlarından bir tanesidir. Yatırımcıların hisse senedi yatırımından beklentisi, uzun vadede kâr payı almak; kısa vadede ise fiyat değişikliklerinden yararlanmaktır. Her iki durumda da işletmelerin performansı önem kazanmaktadır. İşletmelerin performansını ölçen unsurlardan bir tanesi ise kârlılık oranlardır.

$\mathrm{Bu}$ çalışmada kârlılık oranları ile hisse senedi getirileri arasında anlamlı ilişki olup olmadığı araştırılmış ve yatırımcılara, yatırım kararlarını belirlemede yardımcı olabilmek hedeflenmiştir. Hisse senedi getirileri ile kârlılık oranları arasında anlamlı ilişkiler bulunduğu takdirde; yatırımcı bu ilişkileri de dikkate alarak yatırım portföyünü oluşturacaktır. Böylelikle nispeten riskli bir yatırım aracı olan hisse senedi yatırımlarında, yatırımcı daha güvenli hareket edebilmiş olacaktır. Bu kapsamda Borsa İstanbul'da yer alan işletmelerin finansal verileri kullanılarak 2011-2015 yılları arası analiz edilmiştir.

Yapılan analiz sonucunda; hisse senedi getirisi ile öz kaynak kârlılı̆̆ ve brüt satış kârlılığ1 arasında doğrusal ilişki; faaliyet kârlılığ1 ile ters yönlü ilişki bulunmuştur. Net kâr marjı ve aktif kârlılığ 1 arasında ise anlamlı ilişki bulunamamıştır. Araştırmada bulunan hisse senedi getirisi ile öz kaynak kârlılı̆̆ ve satış kârlılığı arasındaki pozitif ilişki Aktaş ve Güngör \& Kaygın'ın çalışması (Aktas, 2009; Güngör \& Kaygin, 2015) ile uyumludur. Güngör ve Kaygın'da (Güngör \& Kaygin, 2015) çalışmalarında net kâr marjı ve aktif karlılığı ile hisse senedi getirileri arasında ilişki bulamamıştır. Faaliyet kârlılığındaki ters yönlü ilişkinin de faaliyet dışı kârlılık nedeniyle olabileceği düşünülmektedir. Gelecekte yapılacak yeni çalışmalarda, hisse senedi ile kârlılık oranları arasındaki ilişkilere sektörel bazda bakılarak; sektörler arası karşılaştırma yapılması önerilebilir. 


\section{Kaynakça}

Aktas, M. (2009). İstanbul Menkul Kiymetler Borsasında hisse senedi getirilileri ile ilişkili olan finansal oranların araştırılması. Journal of the School of Business Administration, Istanbul University, 37(2), 137-150.

Baltagi, B. H. (2005). Econometric Analysis of Panel Data (Third ed.). England: John Wiley and Sons, Ltd.

Borsa İstanbul. (2016). from https://datastore.borsaistanbul.com Erişim: 20.12.2015 - 04.07.2016

Büyükşalvarci, A. (2010). Finansal Oranlar İle Hisse Senedi Getirileri Arasındaki İlişkinin Analizi: İMKB İmalat Sektörü Üzerine Bir Araştırma. Journal of Accounting \& Finance (48).

Dehuan, J., \& Jin, Z. (2008). Firm Performance and Stock Returns: An Empirical Study of the Top Performing Stocks Listed on Shanghai Stock Exchange. Academy of Accounting and Financial Studies Journal, 12(1), 79.

Ege, İ., \& Bayrakdaroğlu, A. (2009). İMKB Şirketlerinin Hisse Senedi Getiri Başarılarının Lojistik Regresyon Tekniği İle Analizi. Zonguldak Karaelmas University Journal of Social Sciences, 5(10).

Güngör, B., \& Kaygin, C. Y. (2015). Dinamik Panel Veri Analizi ile Hisse Senedi Fiyatını Etkileyen Faktörlerin Belirlenmesi. Kafkas University. Faculty of Economics and Administrative Sciences. Journal, 6(9), 149.

Güriş, S. (2015). Stata ile Panel Veri Modelleri. İstanbul: Der Yayınları.

Habib, Z. I. K., \& Khan, M. A. (2012). Dividend Policy and Share Price Volatility: Evidence from Pakistan. Global Journal of Management and Business Research, 12(5).

Kamuyu Aydınatma Platformu. (2016). from https://www.kap.org.tr/ Erişim: 20.05.2016

Khan, K. I., Aamir, M., Qayyum, A., Nasir, A., \& Khan, M. I. (2011). Can Dividend Decisions Affect the Stock Prices: A Case of Dividend Paying Companies of KSE. International Research Journal of Finance and Economics, 76(68), 69-74.

Omran, M., \& Ragab, A. (2004). Linear versus non-linear relationships between financial ratios and stock returns: empirical evidence from Egyptian firms. Review of Accounting and finance, 3(2), 84-102.

Oruç, E. (2010). İMKB'de İşlem Gören İşletmelerin Hisse Senedi Getirileri İle Çeşitli Finansal Göstergeleri Arasındaki İlişki. Hitit Üniversitesi Sosyal Bilimler Enstitüsü Dergisi, 3(1-2).

Ozen, E., Yesildag, E., \& Soba, M. (2015). TOPSIS Performance Evaluation Measures and Relation Between Financial Ratios and Stock Returns. Journal of Economics Finance and Accounting, 2(4). 
Yalova Sosyal Bilimler Dergisi

Sakarya, S., \& Yildirim, H. H. (2016). Determining the Relation Between Financial Performance and Stock Returns of Energy Companies on Borsa Istanbul with Panel Data Analysis. Journal of Economics Finance and Accounting, $3(1)$.

Yerdelen Tatoğlu, F. (2013). Panel Veri Ekonometrisi (2 ed.): Beta Basım.

Yılgör, A. G. (2005). İşletmelerin Borçlanma Düzeyindeki Değişimin Hisse Senedi Getirileri Üzerindeki Etkileri. Dokuz Eylül Üniversitesi İI.I.B.F. Dergisi, 20(1). 